\title{
I BELIEVE IN THE HOLY EARTHY CHURCH: TOWARD AN ECOLOGICAL REINTERPRETATION OF THE HOLINESS OF THE CHURCH
}

\author{
David N Field \\ Research Fellow, University of Zululand \\ Academic Coordinator, Methodist e-Academy
}

\begin{abstract}
This article develops a re-interpretation of the holiness of the church. It comprises two main sections. The first re-examines the motif of holiness by critically examining use of this motif in selected biblical traditions. This will form the basis for the development of an ecological understanding of holiness. The second part will examine what on earth it means to confess that the church is ecologically holy given, its all too obvious failures and the pervasive influence of the socio-cultural and politico-economic forces that are destructive to the earth.
\end{abstract}

Key Words: Holiness, Church, Ecclesiology, Eco-theology, Earth

Christians confess that they believe in "the one, holy, catholic and apostolic church". The theological challenge posed by the eco-justice crisis demands that we rethink what it means for the church to be the church in relation to both the renewed awareness of the ecological interdependence of all life on earth and the destructive impact of contemporary globalised society. A potentially fruitful way of doing this is to develop an ecological re-interpretation of the traditional marks of the church and in this case the holiness of the church.

\section{The Earthiness of the Church - Preliminary Considerations}

An eco-ecclesiology affirms that the church is an earthy church. The church is the church only as it exists as a community of communities in deep interrelationship with the earth. This assertion is grounded in three New Testament images of the church. ${ }^{1}$ The church is portrayed in the New Testament as the people of God; an image that emphasises the relationship between the church and Israel. Israel's existence as the people of God was profoundly interconnected with its dynamic relationship with the land. Paul makes two interesting moves: on the one hand he describes the church as receiving the blessings promised to Abraham through its union with Christ. On the other hand he glosses God's promise of land to Abraham as a promise to the world. (Romans 4:13). The church, as the people of God, does not inherit a particular land but the earth, not in the sense of institutional churches taking possession of large tracts of land as they did during the colonial era - rather in the sense that the church is the transnational people of God scattered

A detailed justification and exposition of this assertion lies beyond the scope of this article. What follows is a brief outline which I hope to develop in future research. For a preliminary reflection on an ecological ecclesiology see Field 2001. 
throughout the world constituted by communities of people who live in dynamic interdependence with the earth.

The second image is that of the body of Christ. For Paul the physical bodies of Christians are the members of Christ - the parts of Christ's body. ${ }^{2}$ Hence the church comprises human bodies that are related to each other by virtue of their relationship with Christ. These bodies were, according to the second creation story, created from the dust of the earth. As human beings we exist as embodied creatures in a complex network of ecological relationships with the earth. The church is composed of embodied beings who are integral parts of the earth community. The church as the body of Christ thus exists only as it exists concretely in dynamic relationship with the earth.

The church is the first fruits of the new creation. Yet the new creation is portrayed as a new heaven and a new earth - it is the redemption of the earth community. To confess that the church is the first fruits of the new creation is to affirm that as a consequence of the presence of the Spirit the church is that part of the earth community which experiences in a proleptic and partial manner the renewal creation as an anticipatory sign of the eschatological redemption of the earth. The confession of the eschatological identity of the church is to affirm its earthliness both as a present reality and as an eschatological hope.

\section{The Holiness of the Church - Preliminary Considerations}

Fundamentally holiness refers to the Sphere of the divine - hence the attribute of holiness has historically served to emphasise that the church has a distinctive identity as a community called out by God, that is shaped on the one hand by its dedication and consecration to God, and on the other by its separation from and contrast to those elements of human society that do not share this consecration. The understanding of this dedication and contrast has been configured in relation to differing understandings of the character and purpose of God in relation to the socio-political and religio-cultural context. Hence the meaning ascribed to the holiness as a mark of the church has, over the centuries, been the subject of debate. While a detailed discussion of this lies beyond the scope of this article, two significant dimensions are of significance for the following discussion. The first is that the affirmation of the holiness the church is always contested by the reality of the sinfulness of the church. The tension between the holiness and the sinfulness of the church leads to the second significant dimension of the historical debate, that is that the holiness of the concrete church is constituted by a dialectic of an indicative and an imperative. Holiness is both a dimension of the identity of the church as church and a dimension of its vocation in the world. Because the church is holy it is called to become holy. Yet the church is only holy as it strives to become holy.

\section{Biblical Perspectives on the Holiness of God's People ${ }^{3}$}

The Bible provides a multiplicity of interpretations of the motif of holiness; this article will examine the understanding of holiness found in the Priestly traditions, First Isaiah, the teachings of Jesus and Paul's letters. Within the diversity of interpretation there are two common themes. The first is that holiness is primarily the property of a community - Israel

See I Corinthians 6.15

I have discussed the issue of the use of the Bible in eco-theology in Field 2009 and 2012. What follows is based on conclusions of a variety of biblical scholars. This article is not a work of biblical scholarship but a systematic theological reflection informed by the conclusions of biblical scholarship. I have not entered into debate concerning different interpretations; further details can be found in the literature cited in the footnotes. 
or the church. It is only secondarily a property of individuals who are holy by virtue of their participation and function within the community. The second is that holiness has both an indicative dimension and an imperative dimension. By virtue of God's electing and redeeming action Israel and the church are holy communities. The corollary of this is that they are called to be holy - to become what they are.

\section{Purity and the Patterns of Creation - the Priestly Traditions}

Central to the Priestly traditions of the Pentateuch is the understanding that God had called Israel to become the people of God - a people living in a unique relationship with God. By virtue of this relationship they are a holy people. However, this holiness was to be expressed through a distinctive lifestyle. While the date and composition of the Priestly traditions remains a matter of debate it is generally accepted that their final form was composed as charter for the returned exiles. ${ }^{4}$ For our purpose it is sufficient to identify some key themes. ${ }^{5}$

- YHWH brought Israelite out of Egypt into the YHWH's land so that they would become the people of YHWH amongst whom YHWH would dwell. The presence of YHWH amongst the people was what distinguished Israel from other nations constituting it as a holy people and requiring Israel to adopt a distinctive lifestyle shaped by its consecration to the God of the Exodus. ${ }^{6}$ Israel was to be holy because God is holy (Lev.11:45 \& 19:2). This holiness was to be actualised within the boundaries of and in relation to a particular land. Here Israel was to live differently from the way that other nations lived in their lands. While the priestly traditions do not describe the land as holy, Israel's holiness in its indicative and imperative dimensions is intricately entwined with her indwelling YHWH's land.

- Holiness, in the final form of the priestly traditions, is a comprehensive way of life that encompasses the relationships between Israel and YHWH, amongst the people of Israel and between Israelites and resident aliens, between people and fauna, and between the people and the land. The cult and the regulations associated with it play a key role in integrating these diverse relationships.

- Holiness entails making and maintaining of correct distinctions. There are two sets of fundamental distinctions: That between holy and common and that between pure and impure, that which is holy is that which belongs to the realm of the divine. Within the realm of the divine there are grades of holiness; e.g. Israel as the people chosen by God is holy, the priests are holier, and the high priest is the holiest person. ${ }^{7}$ Holiness is contrasted with the common or the everyday. While holiness has ethical dimensions it is not primarily an ethical category and the common is not equivalent to sinful. The distinction between the pure and the impure is of great significance for impurity must not be brought into contact with that which is holy. There are various forms and degrees of impurity - some are permanent while others are temporary. Temporary impurity can be removed by the appropriate ritual.

- The relationship between sin, morality and impurity is complex. Impurity can be divided into two categories. Jonathan Klawans designates these as 'ritual impurity' and

See Carr 2011:214-221\&292-303.

In what follows I have drawn on discussions in Douglas 1999, Milgrom 2004, Jenson 1992 and 2003, Crüsemann, 2005: 323-380, and Dale 1985:145-188.

See Crüsemann 2005:350-355.

See Jenson 1992. 
'moral impurity'. ${ }^{8}$ Ritual impurity is encountered almost inevitably in daily life. What is important is that a person who becomes 'ritually impure' must not enter the sphere of the holy and must perform purification rituals. Failure to perform these rituals constitutes a serious sin. Certain sins such as idolatry, murder and sexual violations result in 'moral impurity'. This cannot be ritually cleansed though it can be atoned for. The build-up of 'moral impurity' would result in the land being defiled. Further the Holiness code expounds Yahweh's command that the people be holy as requiring ethical conduct which expresses love for neighbours and resident foreigners; that is conduct that accords with the character of YHWH revealed in the Exodus.

- Underlying much of cultic symbols is a contrast between life and death. Death and that which in various ways is symbolic of death is impure. Thus Milgrom argues that "the identification of impurity with death must mean that holiness stands for life". 9

- An important part of maintaining purity is correctly classifying fauna into what could and could not be eaten. ${ }^{10}$ In relation to land animals this entailed distinguishing between clean and unclean animals. It was permissible to have physical contact with an unclean animal while it was alive but once it was dead physical contact led to impurity. The Priestly tradition (in contrast to the Deuteronomic tradition) describes the forbidden flying and water creatures not as 'unclean' but as being an 'abomination' that is, according to Mary Douglass, something to be shunned. While the reasoning behind these distinctions remains a matter of debate many reflect the understanding of creation expressed in the first creation. God brought order out of chaos by creating and maintaining distinctions. God created distinct realms within creation and fauna that conform to the typical characteristics of that realm and are permitted while those that do not are forbidden. Fish with fins and scales may be eaten as the typical means of locomotion in water is swimming; water creatures with legs, the typical means of locomotion on land, may not be eaten. A further dimension observed by Douglass is that many of the water and flying creatures that are to be shunned described as 'swarming' a word often used to describe fertility and abundance. In Genesis 1 God commands the waters to "bring forth swarms of living creatures". She proposes that as the holy of holies is associated with fertility such swarming creatures belong to God and hence cannot be sacrificed or eaten. Maintaining holiness required the careful observation of creation.

- The combined effect of three sets of laws restricted the killing of animals and promoted a respect for life. The dietary laws greatly restricted which fauna could be eaten and which bodies could be used for making clothing, tools and other necessities. The Priestly traditions limited the killing of domestic animals to killing for sacrifice forbidding secular slaughter. Further the eating of blood was forbidden as blood symbolised life that belonged to God. Life belongs to God and can only be taken under clearly specified conditions.

- Holiness was deeply bound up with the way one related to the land. The land belonged to YHWH and the people were aliens and tenants. YHWH was present in the land and will ensure its fertility if the people live in an appropriate relationship to the land. This appropriate relationship entailed making correct distinction in relation to time giving rise to the Sabbath, Sabbath year and Jubilee year. While these times combined ritual

\footnotetext{
8 Klawans 2000:21-42. As Klawans notes, these designations are not entirely satisfactory.

9 Milgrom 2004:12.

10 For a detailed discussion of what follows issues see Douglass 1999:135-175 and Milgrom 2004:101-121.
} 
activity with social justice and a concern for the earth and our fellow creatures, the Priestly traditions emphasised that they were for the benefit of the land. Failure to observe these times would result in exile so that the land could enjoy its rest.

In the Priestly traditions Israel was a holy people because it has been called, through the exodus, into a particular relationship with the YHWH the creator and source of life and fertility. Integral to this relationship is the calling of Israel live in the presence of YHWH in dynamic interdependence with YHWH's land. Israel's holiness was thus constituted by its relationship both to YHWH and YHWH's land and was to be expressed in a communal lifestyle that promoted justice, respected life, paid careful to creation and cared for the land.

\section{Holiness and Justice - the Isaianic Vision}

A characteristic feature of the writings of Isaiah of Jerusalem and his disciples is the way in which they integrate the central motifs of holiness and social justice. ${ }^{11}$ In his inaugural vision Isaiah encountered YHWH as the Holy One who requires purity from the people. The continuing significance of holiness is emphasised in the use of the title, the Holy One of Israel, for YHWH. However, Isaiah understood YHWH's holiness in relation to righteousness and justice - that is God's faithfulness to the covenant relationship with Israel expressed in action to maintain the rights the poor, the exploited and the oppressed. ${ }^{12}$ The distinguishing characteristic of YHWH was his passion for social justice and hence YHWH required that the Israel's identity as a holy people be expressed through a similar passion. YHWH's holiness was proclaimed when the lifestyle of YHWH's people's was characterised by justice.

In bringing this message Isaiah used the language of the cult. Israel as the holy people of YHWH and the temple as the dwelling place of YHWH are being defiled by injustice. This impurity cannot be cleansed through sacrifice because injustice defiles the practices of the cult. It can only be cleansed through concrete repentance - that is the turning away from the practices of injustice and the implementing justice. In the same way that the people sought YHWH through the cult they must now seek justice in society. Isaiah was not opposed to the cult but insists that its validity was dependent upon the pursuit of justice in society; injustice renders the rituals of the cult repulsive to YHWH. Failure to respond to God's call to justice would result in judgment. Isaiah held forth the hope that God will act through a future ruler who will establish justice. The consequence of this would be the establishment of shalom - that is comprehensive well-being of the people in dynamic harmony with a renewed creation. While Isaiah emphasised the imperative dimension of holiness as social justice his message must be seen against the background of the indicative. Israel was the people of YHWH whose holiness was constituted by the presence of YHWH in the temple. It was precisely this indicative holiness that makes Israel's injustice so perverse. A lifestyle of injustice was a fundamental contradiction of its status as the people of the Holy One who was passionately committed to justice.

11 Isaiah 1-39 probably contains oracles from Isaiah and from later disciples who interpreted his ideas in relation to the events leading up to the exile. A few oracles are from even later. See Leclerc 2001:16-28. In what follows I have drawn on the discussion in Koch 1982: 105-156, Leclerc 2001, Moberly 2003, and Gammie 1989:71-96.

12 See Birch 1991:153-157 and Wright 2004:253-279. 


\section{Jesus' Reconfiguration of Holiness}

There is remarkable absence of the language of holiness in the gospels. ${ }^{13}$ This does not mean that the issues usually described by this language are absent. Jesus proclaimed that in his ministry God was acting in a new way to renew and transform Israel. The renewed Israel was manifested in communities of disciples drawn largely from the poor and those excluded by the religious establishment. Jesus affirmed that they were the objects of God's favour and the agents of God's reign. The communities of disciples were called to embody the transforming reign of God by living lives characterised by self-giving love for neighbours and enemies, a rejection of hierarchies of power and status and a rejection of the pursuit of wealth.

While Jesus' attitude to the purity laws is a matter of debate it can be argued that Jesus demonstrated a remarkable freedom with regard to issues of ritual purity. ${ }^{14} \mathrm{He}$ emphasised that it was actions and attitudes contrary to self-giving love that brought impurity. He included in his community those whom others rejected as impure and sinful. In his acts of healing he touched or was touched by those who were categorised as unclean because of their diseases. What is remarkable was not that Jesus risked being made ritually impure (something that was unavoidable and easily remedied) but that he did so in a manner in which he assumed the role of the temple and the priesthood in dispensing forgiveness. It was thus as the representative of God - as the holy one - that he did this. In the Priestly traditions when the impure came into contact with the holy it was destroyed. In Jesus when the impure was brought into contact with the holy it was healed and thereby purified. In Jesus holiness was power bringing life.

Jesus grounded both his mission, his creative freedom with regard to the purity laws and his call to a transformed lifestyle in an understanding of God's inclusive love and compassion. The followers of Jesus were called to emulate this love. Thus the Gospel writers reinterpret the Priestly traditions' call to be holy as God is holy as to "be perfect ... as your heavenly Father is perfect" (Matthew 5:48) or to "be merciful as your Father is merciful" (Luke 6:36). While Jesus teaching and embodying the reign of God paid little direct attention to the relationship between human beings and the non-human creation, he emphasised that God cares for all creation.

Hence for Jesus holiness is the power of God's transforming love which creates a new community out of those who are despised and rejected, and which is to be embodied by this new community in a lifestyle of self-giving love.

\section{Conformity to the Crucified Christ - A Pauline Perspective}

Paul re-introduced the language of holiness but his understanding had been radically reshaped by the conviction that God had acted in the crucifixion and resurrection of Jesus to inaugurate the eschatological new creation. As a consequence Christian communities live within the fracture caused by the eruption of the new creation in the midst of the old. Paul sought to reconfigure their vision and praxis around the shocking thesis that God was most clearly revealed in the cross. ${ }^{15}$ Paul's vision of the world rejected the polar opposites that characterised both the Jewish and Gentile interpretations of reality and replaced them with

\footnotetext{
13 For discussion of various opinions on Jesus and holiness see Borg 1998, Borg, 2006, Carey 2009 and Dunn $2003 a$.

14 See the discussions in Borg 1998:135-212, Carey 2009: 37-54, Dunn 2003b: 563-583 and Meier 2009:342-477.

15 See Martin 1997, Gorman 2001:9-18, 2009:1-39, and Couser 1990:25-51.
} 
the opposition between the powers of the old and the new creation exposed by the cross. In the light of the cross the distinctions created by the law (circumcised and uncircumcised) and those viewed as rooted in creation (male and female) have no significance anymore. Hence the categorisation of the natural world into clean and unclean, which underpinned the purity and holiness system rooted in the Torah, was abolished. The motifs of holiness and purity are retained but they are they are reconfigured to "offer a radically new interpretation ... moulded by the gospel of the Messiah who was crucified by Rome but raised and exalted by God." 16

In a world fractured by the in-breaking of God's reign the holy was identified with that which belonged to the new creation brought about by the eschatological presence of the Spirit and the unholy with that which belonged to the sin dominated old creation. The church was the community of those who have been united to each other through their union with the crucified Christ through faith expressed in baptism of Christians. Through their relationship with Christ they are united with his crucifixion and hence have died of old age and are liberated from its powers. Through the presence and activity of the Spirit they are incorporated into the community of the new creation and empowered to live in conformity to the crucified Christ. They have been sanctified or made holy. This holiness must now be given expression through a Spirit enabled communal and personal lifestyle of conformity to the crucified Christ. Paul explicates the significance of this in a multifaceted way. A number of recurring themes are significant for our purposes:

- Conformity to the cross stood in direct contrast to the dominant models of power in the Roman Empire and turned upside down the ideological hierarchies of honour and shame that characterised Greco-Roman society. The community of the cross was one that valued the despised, the marginalised, the poor and the weak.

- Conformity with the cross expressed itself in a pattern of life that entailed the renunciation of legitimate privilege and in some cases the entering into suffering in order to serve the good of others.

- Conformity to the cross put self-giving love at the centre of the Christian life. The cross was the ultimate expression of the love of God the Father and of Christ Jesus. Christians were empowered and called to express the same kind of love to others.

- As a consequence of being united with Christ's crucifixion the bodies of Christians are united to the body of Christ indwelt by the Spirit which will be resurrected to share in the eschatological new creation. The bodies of believers and the church as a community of embodied persons are now the temples of the Spirit. By virtue of union with Christ the actions of the Christian's body are the actions of a part of the body of Christ and therefore believers are called to bodily holiness. This is the recognition that one's body belongs to Christ and hence one must offer one's body to the Lord for benefit of others and reject uses of the body that harm others or are incompatible with one's being the temple of the Spirit. Yet there is an ambiguity as Paul appears to have viewed not only how we use our bodies but also some aspect of our bodily existence as evil.

- In Romans 8:18-25, Paul views the natural world from the perspective of the eruption of the new creation in the cross and resurrection integrating the suffering of Christians with that of the natural world. Christian and the natural world long for redemption of their physical existence. The redemption of creation will take place when the children of God are revealed. Creation groans in expectation of this, Christians share in this

16 Gorman 2009:105. In what follows I have made extensive use of themes from Martin 1997 and Gorman 2001 \& 2009, I have also drawn on Brower 2010, Couser 1990, and Harrisville 2006. 
groaning as a consequence of the work of the Spirit. Thus the Spirit led conformity with Christ's crucifixion leads to solidarity with the suffering creation. It is possible that the revealing of the children of God referred not only to the resurrection but to the present revealing of people as the children of God as they are conformed to the crucifixion. Thus the hope of creation would be partially fulfilled through the holiness of the Christian communities. ${ }^{17}$

\section{Contours of an Ecological Reconfiguration of the Holiness of the Church}

The Bible provides diverse interpretations of holiness that relate key theological ideas to significant contextual issues in the context of particular socio-cultural environments. As such these interpretations provide exemplars for our constructive theologising. The urgencies of the eco-justice crisis challenge traditional ecclesiologies and inspire an ecological reconfiguration of the holiness of the church. Such a reconfiguration must engage three dimensions: The first is the relocation of holiness around God's action in Jesus Christ in the New Testament traditions. The second is the eco-theological recovery of the earthy character of the church. The third is the ethical challenge posed by the ecojustice crisis.

The holy is the sphere of the divine presence and thus perceptions of the character of God shape our understanding of the character of holiness. For the Priestly tradition it was God as the creator of order, life and fertility, for Isaiah it was God who was passionate for justice, for Jesus it was God who loved and showed compassion towards all human beings (and the rest of creation) and for Paul it was the multifaceted God revealed in the cross. An eco-theological perspective draws on these and other images affirming that God is revealed in Jesus Christ as the creator who blesses creation with life and fertility, as a loving parent who has compassion on all God's creatures, as a God of justice who sides with the excluded, the oppressed and the poor, and as the One who enters into the pain and suffering of God's creatures in order to bring about healing, justice and renewal for all creation. It is this God who has called the church in its earthiness to be the sign and for taste of the eschatological new creation through union with the crucified Christ by the presence of the Spirit.

The indicative holiness of the church is constituted through its calling by God into this particular relationship. This holiness has three dimensions:

- It is the affirmation that the church in its earthiness as the body of Christ composed of human bodies is holy. This is an affirmation of bodily life in all its complexity and its physicality for the human body is an integral part of creation and thus in affirming the body we affirm earthly life in its ecological complexity. The church is holy not in its distinction from the earth but in its participation in and relationship with the earth community through its bodiliness. To affirm that this church in its earthiness is to confess that God claims, affirms and blesses the earthy bodily character of the church. God as the sources of life and fertility affirms as holy the physical, the sensual, the biological, the fecund and the fruitful dimensions of earthly life.

- To affirm that the church is holy is to affirm that it has a particular identity - an identity that distinguishes it from the 'world' but not from the earth. The church is that part of the earth community which is sanctified through its union with the crucified Christ. It is its union with the crucified Christ that shapes its particular identity. As the community

17 This is argued in detail in Jewett 2007:508-521. 
of the crucified the particular identity of the church stands in contrast to the hierarchies of power, exploitation and status that characterise old creation. The place of the church is among the marginalised, the rejected and the abused.

- To affirm that the church is holy is to confess that by the presence of the sanctifying Spirit the church is the sign and proleptic presence of the eschatological renewal of creation. Through the Spirit God sanctifies a portion of the earth community and dedicates it to Godself and to God's purpose for the whole of creation. The sanctifying presence of the Spirit unites the church with the suffering earth community as both look forward to the renewal of creation. Hence the sanctification of the church as a part of the earth community is the sacrament of God's promise to renew the earth community in its completeness.

The indicative ecological holiness of the church cries out for actualisation in the life of the church, thus giving rise to the imperatives of ecological holiness.

The first is the affirmation that God calls the church to be holy as God is holy - that is to be holy is to be caught up into the dynamic of God's love for creation and to be empowered and transformed by this love so that we love our fellow human beings, the earth and all the creatures of the earth.

The second is the affirmation that the polyvalent message of the cross which must be related to issues of eco-injustice. This calls the church to participate in cruciform life of Christ by the adoption of a multifaceted lifestyle of kenosis for the good of the earth. This means learning to live lightly on the earth, reducing the consummation of resources, rejecting hierarchies of power and wealth that benefit us but exploit both humans and the earth, working for the empowerment of marginalised and exploited groups so that they are enabled to care for creation, and redirecting politics, business and technological development for the comprehensive well-being of the earth and its inhabitants. The subversive message of the cross calls us to recognise that the healing of earth is integrally related to the establishment of justice for the oppressed and marginalised.

The third is to affirm the Spirit of holiness present within the church, drawing the church into increasing solidarity with the suffering creation in the expectation of the redemption of all things. It is this hope that should give greater intensity to the churches solidarity with suffering creatures causing it to cry out for the healing of the earth. Ecological holiness is not a list of activities that we perform - it is a Spirit directed and Spirit empowered pilgrimage into increasing solidarity with the earth in its travail. Our praxis of earth healing is a response to the work of Spirit within us personally and corporately. Positively this means that the church must develop creative ways to integrate its solidarity with the earth in its suffering and put hope into its liturgical life and its praxis of mission.

The fourth dimension is the affirmation that the resurrection is the affirmation of the bodily character of holiness for we are united to Christ in our bodiliness, indwelt by the Spirit and hoping for the resurrection. There is no holiness that is not bodily holiness. Our bodily existence is to be shaped by our being in Christ. To be bodily holy involves both the affirmation and celebration of life and a bodily life that reverences life and which facilitates it's flourishing in all its ecological diversity. Thus there is a need to recover the respect for life embodied in the priestly food laws, not in literalistic obedience but in seeking creative ways to reverence life and reduce our dependence on the death and suffering of our fellow creatures. One is bodily holy when one promotes healing of the earth and opposes the forces of destruction and death that exploit the earth and humankind. 
The fifth dimension is to affirm that holiness means living in a way that pays careful and creative attention to the dynamics of created life. While the priestly purity laws encouraged and facilitated such an attitude to creation they were based on an obsolete understanding of creation. Paul's meditation on the groaning of creation further encourages us to pay empathetic attention to the suffering that is an inherent component of all life on earth. Ecological holiness is dependent upon an empathetic awareness of the dynamic and diverse interdependence of life on earth and the desire to live creatively in accordance with it.

\section{The Ecological Holiness and the Sinfulness of the Church}

In contrast to its confession, the church in its concrete reality displays its sinfulness. It has embodied values and engaged in praxes that are contrary to the revelation of God in the crucified Christ.

\section{Interpreting the Ecological Sinfulness of the Church}

A significant development in the 20th and 21st centuries has been the emergence of ecclesial repentance as an integral component in the life of the church. Churches have moved beyond general recognitions of the sinfulness of the church to the explicit recognition that particular elements of their past and present are sinful; they have confessed their failure and asked for forgiveness from the victims and from God. ${ }^{18}$ The theological consequence of this is an increasing recognition that the holiness of the church can only be understood in relation to its sinfulness and accompanied by a rejection of theological moves that have attempted to distance the 'genuine' church from the concrete church and its sinfulness. ${ }^{19}$ There is no other church than the church that exists concretely in its brokenness. It is this church that Christian confesses to be holy. An understanding of the ecological holiness of the church is thus inseparably interrelated with an understanding of its ecological sinfulness.

The sinfulness of the church can be seen in three areas: First, where churches, related institutions and their representatives have acted in ways that are contrary to what the church itself proclaims to be the values of the gospel; second, where the churches in hindsight recognise that it's past theology and praxis have been contrary to the revelation of God in Christ. The third is where a church as consequence of its participation in a given society has been implicated in the evil of that society against the best intensions of the church. The ecological sinfulness of the church can be seen in all three areas. Churches and theologians have legitimated and some continue to legitimate the exploitation of the earth through theologies of human dominion, anthropocentric soteriologies and spiritualised eschatologies. Members of the church and churches continue to participate in earth destructive lifestyles despite the growing affirmation of Christian ecological responsibility. In the globalising world it is almost impossible to escape entanglement with institutions and systems that pursue economic gain at the expense of humanity and the earth. The church participates through its financial transactions, its participation in commercial activity and its dependence on the products of transnational business.

\footnotetext{
See Bergen 2011.

19 See for example Berkouwer 1976:334-357, Kung 1968:319-343 and Healy 2000:1-51.
} 


\section{Ecological Holiness under the Sign of the Cross}

The concrete communities of believers can only confess their faith in the ecological holiness of the church under the sign of the cross. The identity of the church is constituted by the cross for it is the cross which manifests its acceptance by God, embodies its dedication to God and determines its relation to the society in which it exists.

To confess under the sign of the cross is to confess that the church only exists by virtue of the crucifixion. It lives under the sign of God's costly forgiveness that brought it into being and it continues to exist as the church only as it recognises its dependence on the forgiving grace of God. Under the cross the church acknowledges that it has sinned against God, human beings and our fellow creatures. In its sin, it is no different from the world, rather it is complicit in the sins of the society in which it exists. The church under the cross stands in solidarity with the world and rejects all claims to moral superiority. ${ }^{20}$ In confessing its $\sin$ it affirms its faith in, identification with and consecration to its crucified Lord who died as one rejected by God and humanity. If it denies or obscures its sinfulness it rejects the cross and is no longer living in conformity with its crucified Lord. Hence it is in its confession of sin that it gives expression to its identity as the community called out to follow the crucified Lord - that is its holiness. Paradoxically the church manifests its holiness in the very act of confessing it sinfulness. ${ }^{21}$ This cannot be a general acknowledgement of the sin of the church - that is that it exists simul justus et peccator. It must be the concrete confession of its specific sin. Thus its ecological holiness is manifested in its particular confession complicity in the exploitation and destruction of the earth.

To confess under the sign of the cross is to affirm that the call to ecological holiness is a missiological call. It is a call to follow Christ into the brokenness of the world to be a sign of the healing of the earth. ${ }^{22}$ Thus holiness is not to be confused with the pursuit of moral innocence or purity or with the separation from society on the contrary; it is to enter into and engage society in all its moral ambiguity, political complexity and human messiness in order to be an agent of healing and transformation. An ecologically holy church has learnt from Dietrich Bonhoeffer that it is called to follow Christ through the assumption of vicarious responsibility for the world in its sinfulness. ${ }^{23}$ To do so entails entering into and assuming the guilt of the world. Trusting in the justifying action of God in the cross it moves beyond moralistic judgments and the pursuit of the absolute good to kenotically serve humanity and the earth. This involves taking concrete action in a complex world such concrete action is never without limitations, ambiguity, ignorance and error. To fail to act or to pursue the moral ideal at the expense of our fellow human beings and the earth is to reject the way of the cross. Paradoxically the desire to be morally pure and to avoid guilty is thus the opposite of holiness that is a life of conformity to the cross. The ecologically holy church does not fear the contamination that comes from engaging the complex socio-economic web that is exploiting the earth but rather in humble boldness it engages society in a costly but transformative way as a proleptic sign and expression of God's eschatological healing.

The church under the sign of the cross is a community that is motivated and empowered by the Spirit to engage in a process of transformation so that its life has fuller expression to God's kenotic love for creation manifested on the cross. Such a process arises out of its

\footnotetext{
20 See McBride 2012:57-86.

21 See Moltmann 1977:352-354 and Webster 2003:73-74.

22 See Hooker and Young 2010.

23 See Bonhoeffer 2005:246-298, McBride 2012:87-146 and Schliesser 2008.
} 
confession of its sin and its concrete engagement in the world. Through confession of sin it enters into the transformative spiral of change and engaged praxis that leads communal and personal growth in ecological holiness. As churches become aware of ecological destruction and their role in the exploitation of the earth they re-examine their faith and praxis. Such a re-examination leads to a new engagement within society and the reformation of their lifestyle leading to new and deeper understandings of ecological holiness and of their own brokenness. This in turn leads to new confession and renewal of their faith and praxis and so the spiral continues. Here the thought of John Wesley provides some significant insights. For Wesley holiness is about transformation of inner attitudes and outward actions through the dynamic interaction of a disciplined communal life, communal worship and personal devotion and concrete praxis. ${ }^{24}$ Ecological holiness as communal and personal transformation arises out of engagement with God in the communal liturgy of the church and in personal devotion, the adoption of a disciplined self-sacrificial lifestyle and a praxis of bearing witness to God's reign by active engagement in acts of justice and compassion to toward the earth and it creatures. These three dimensions are integrated with each other: God's transforming grace is to be experienced not only in the traditional practices of worship and personal devotion but more so in the practice of active love for our fellow human beings and the earth. Concrete engagement for the good of our fellow human beings and the earth is a means by which we experience personal and communal transformation. It is enabled by the creation of disciplined communities of people who reject a lifestyle that is dependent upon the exploitation of the earth and human beings. Active love and a disciplined life are informed, motivated and empowered by engagement in communal worship and personal devotion.

Finally the church that stands under the sign of the cross has learnt to engage in a pilgrimage of solidity to the margins of society to take its place amongst those who have been excluded, exploited and abandoned by the dynamics of globalised society. ${ }^{25}$ On the cross Jesus who welcomed and acted in solidarity with the excluded, was rejected as a sinner, excluded from the Jewish community, tortured and killed by the Romans and perceived to be cursed by God. To be holy is to follow Jesus to the places of rejection and suffering. The

... true holiness of the church is seen ... in the courageous criticism of injustice, acts of solidarity with the poor and the outcast, the sharing of friendship and power with the week and the despised. ${ }^{26}$

A holy church identifies itself with the suffering earth and the human victims of exclusion, injustice and ecological degradation. It laments with them and cries to God for healing, justice and transformation, it protests against their exploitation and prophetically denounces the forces that cause their suffering, and it mobilises its resources to empower them to become agents of justice, healing and transformation

\section{Conclusion}

In the contexts of increasing ecological destruction the church is required to examine what it means to be the church of the crucified Christ. Such a re-examination leads to the conclusion that holiness and earthiness are not antonyms; on the contrary a truly holy

\footnotetext{
24 See Wesley's sermons “The Means of Grace” in Outler 1984:376-397 and “On Zeal” in Outler 1986:308-321 and Rieger 2011:29-43.

25 See Field 2003.

26 Migliore 1991:202.
} 
church is a genuinely earthy church. Hence the church is called in its faith and praxis to enter into transformative solidarity with the earth in its travail to cry out and work for its healing. In doing this it becomes holy as God is holy.

\section{BIBLIOGRAPHY}

Bergen, JM 2011. Ecclesial Repentance: The Churches Confront their Sinful Past. London: T\&T Clark.

Berkouwer, GC 1976. The Church. Studies in Dogmatics. Grand Rapids: Eerdmans. Borg, MJ 1998. Conflict, Holiness and Politics in the Teaching of Jesus. Harrisburg: Trinity Press International.

Borg, MJ 2006. Jesus: Uncovering the Life, Teachings and Relevance of a Religious Revolutionary. New York: HarperOne.

Brower, K 2005. Holiness in the Gospels. Kansas City: Beacon Hill.

Bower, K 2010. Living as God's Holy People: Holiness and Community in Paul.

Milton Keyes: Paternoster.

Birch, BC 1991. Let Justice Roll Down: The Old Testament, Ethics and the Christian Life. Louisville: Westminster/John Knox.

Brown, WP 1999. The Ethos of the Cosmos: The Genesis of Moral Imagination in the Bible. Grand Rapids: Eerdmans.

Bonhoeffer, D 2005. Ethics, Dietrich Bonhoeffer Works vol. 6. Minneapolis: Fortress.

Car, FM 2011. The Formation of the Hebrew Bible: A New Reconstruction. Oxford: Oxford University Press.

Carey, G 2009. Sinners: Jesus and his Earliest Followers. Waco: Baylor University Press.

Couser, CB 1990. A Theology of the Cross: The Death of Jesus in the Pauline Letters.

Minneapolis: Fortress.

Crüsemann, F 2005. Die Tora: Theologie und Sozialgeschichte des alttestamentlichen Gesetzes. Gütersloher: Gütersloh.

Dale, P Old Testament Law. Eugene: Wipf and Stock.

Douglass, M 1999. Leviticus as Literature. Oxford: Oxford University Press.

Dunn, JDG 2003a. Jesus and Holiness: The Challenge of Purity. In: Barton SC (ed.), 2003. Holiness Past and Present 168-192. London: T\&T Clark.

Dunn, JDG 2003b. Christianity in the Making, vol.1. Jesus Remembered. Grand Rapids: Eerdmans.

Field, DN 2003 "On (Re)centering the Margins: A Euro-African perspective on the 'Option for the Poor'." in Rieger, J (ed.). 2003. Opting for the Margins: Postmodernity and Liberation in Theology, 45-69, New York: Oxford.

Field, DN 2001. "The Gospel, the Church and the Earth: Reflections on an Ecological Ecclesiology". Journal of Theology for Southern Africa, no 111, 67-79.

Field, DN 2009. "The Theological Authority of the Bible and Ecological Theology." Scriptura, 101, 206-21.

Field, DN 2012. "Biblische Autorität und christliche Praxis". Theologie für die Praxis 27:1, 23-51. 
Gammie, JG 1989. Holiness in Israel. Minneapolis: Fortress.

Gillian, DS (ed.) 1998. Church, Land and Poverty: Community Struggles, Land Reform and the Policy Framework on Church Land. Johannesburg: South African Council of Churches.

Gorman, MJ 2001. Cruciformity: Paul's Narrative Spirituality of the Cross. Grand Rapids: Eerdmans.

Gorman, MJ 2009. Inhabiting the Cruciform God: Kenosis, Justification and Theosis in Paul's Narrative Soteriology. Grand Rapids: Eerdmans.

Harrisville, RA 2006. Fracture: The Cross as Irreconcilable in the Language and Thought of the Biblical Writers. Grand Rapids: Eerdmans.

Healy, NM 2000. Church, World and the Christian Life: Practical Prophetic Ecclesiology. Cambridge: Cambridge University Press.

Hooker, M. and Young F 2010. Holiness and Mission: Learning from the Early Church about Mission in the City. London: SCM.

Horrel, DG, Hunt, C, \& Southgate, C 2010. Greening Paul: Rereading the Apostle in a Time of Ecological Crisis. Waco: Baylor University Press.

Jenson, P 2003. Holiness in the Priestly Writings of the Old Testament. In: Barton SC (ed.), 2003. Holiness Past and Present 93-121. London: T\&T Clark.

Jenson, PP 1992. Graded Holiness: A Key to the Priestly Conception of the World. Sheffield: JSOT.

Jewett, R 2007. Romans: A Commentary, Hermeneia. Minneapolis: Fortress.

Klawans, J. 2000. Impurity and Sin in Ancient Judaism. Oxford: Oxford University Press.

Koch, K. 1982. The Prophets. Vol. 1. The Assyrian Period. London: SCM.

Kung, H 1968. The Church. London: Search.

Leclerc, TL 2001. Yahweh is Exalted in Justice: Solidarity and Conflict in Isaiah. Minneapolis: Fortress.

Meier, JP 2009. A Marginal Jew: Rethinking the Historical Jesus, vol. 4, Law and Love.

New Haven: Yale University Press.

Martin, DB 2006. Sex and the Single Savior: Gender and Sexuality in Biblical Interpretation. Minneapolis: Fortress.

Martin, JL 1997. Theological Issues in the Letters of Paul. Nashville: Abingdon.

McBride, JM 2012 The Church for the World: A Theology of Public Witness. New York: Oxford University Press.

Migliore, DL 1991. Faith Seeking Understanding: An Introduction to Christian Theology. Grand Rapids: Eerdmans.

Milgrom, J 2004. Leviticus: A Book of Ritual and Ethics. Continental Commentary. Minneapolis: Fortress.

Moberly, RWL 2003. “Holy, Holy, Holy”: Isaiah’s Vision of God. In: Barton SC (ed.), 2003. Holiness Past and Present 122-140. London: T\&T Clark.

Moltmann, J 1977. The Church in the Power of the Spirit: A Contribution to Messianic Ecclesiology. London: SCM.

Outler, A (ed.) 1984. The Works of John Wesley, Vol.1, Sermons IV - 1-33, Nashville: Abingdon. 
Outler, A (ed.) 1986. The Works of John Wesley, Vol.3, Sermons IV - 71-114, Nashville: Abingdon.

Rieger, J 2011. Grace under Pressure: Negotiating the Heart of the Methodist Tradition. Nashville: General Board of Higher Education and Ministry.

Rogerson, J 2003. What is Holiness? In: Barton SC (ed.), 2003. Holiness Past and Present, 3-21. London: T\&T Clark.

Schliesser, C 2008. Everyone who Acts Responsibly becomes Guilty: Bonhoeffer's Concept of Accepting Guilt. Louisville: John Knox.

Webster, J 2003. Holiness. Grand Rapids: Eerdmans.

Wright, CJH 2004. Old Testament Ethics for the People of God. Downers Grove: InterVarsity. 